\title{
Britain's Irish Periphery
}

\section{Raymond Crotty}

The simplistic attribution of Ireland's woes to seven centuries of British rule wears thin as, almost 60 years after an independent Irish State was established, the decline in the number of people at work in Ireland continues. Even the modernised version of the old bogyman, re-labelled 'British neo-colonialism'-to escape which Ireland, with much apparent relief, surrendered a considerable portion of its notlong-won sovereignty to join the EEC-has little credibility left as the slide in job numbers continues, and even accelerates, five years after Ireland joined the EEC. It is time for a reappraisal, and in that reappraisal the insights of development economics promise to be revealing. Moreover, as a well-documented case study of the original colony of the capitalist era, the Irish sequence of growth and decline, of the optimism of independence giving way to the disillusionment of failure, can add much to the corpus of knowledge about the process of both development and undevelopment.

\section{Flank protection}

The thorny subject of Anglo-Irish relations can be viewed instructively in the context of Britain's changing overseas role. Like two grazing animals spanned together, the dominant power pulled the lesser now one way, now another, as it pursued its interests: first carving out the most extensive empire in history; then reaping the fruits of empire; and, more recently, retreating from empire to build a new position for itself on Europe's periphery.

Centuries of desultory, ineffective, pre-capitalist, Anglo-Norman colonising attempts in Ireland preceded the violent, complete conquest of the island that was an early, strategically essential step in Elizabethan England's drive towards overseas greatness. As if to underline awareness of the need for flank protection in the exercise of empire-building, several of England's adventurers in the newly settled American colonies were also to the fore among those who conquered, appropriated and settled Ireland's land with an English protestant garrison, most of whom were settled in the north-east (Wellerstein, 1974: 88).

A secured Ireland was strategically essential for Britain as it established abroad the profitable complementary trading relationships that multi- plied its small initial capital stock. But a secured Ireland, its resources mobilised for the garrison's profit, threatened to flood Britain with competing pastoral products, wiping out the profits from English land that were the principal source of finance for the first stages of imperial expansion. Protests were heard in the House of Commons in 1621, barely two decades after the trade had commenced, against imports of Irish cattle, stated to be 100,000 annually (Clarke, 1966). The figure, though an exaggeration, would have represented in relation to the contemporary population more than Britain's total present meat imports. The Cattle Acts, passed by the Restoration Parliament, banned all imports of Irish pastoral products and isolated pastoral Ireland from its British market, other than as an outlet for English corn, which under the Corn Laws, was dumped in Ireland in most years up to the great divide of 1760 .

\section{The Cattle Acts}

The century-and-a-half between the passing of the Cattle Acts and the Battle of Waterloo, during most of which the British market was denied to Irish pastoral products, was, for Ireland, a period of sustained, rapid growth fuelled partly by exports of linen yarn and cloth to England and of highly processed pastoral products (salted and barrelled butter, beef and pig meat) to other, more distant, markets. Primitive with respect to its population, wealth, and the sophistication of its institutions at the commencement of the period, Ireland, at the end, had a population that was one half and a foreign trade that was one quarter that of England. This record controverts many neo-classical generalisations about economic growth, though not that of the tremendous efficacy of the unbridled pursuit of profit as an instrument for change. Rarely was a society so effectively mobilised to generate profit for its ruling class, with what success may be gauged from the fact that Irish land, that could not be sold for one shilling an acre shortly before the passing of the Cattle Acts, could not be bought for $£ 20$ an acre at the time of Waterloo (Bottigheimer, 1971; Maguire, 1972).

Crucial new features were introduced in the latter part of this period of growth, coinciding, more or less, with the traditionally accepted commencement of the English industrial revolution; with England's transformation from a grain-exporter to a grain-importer in most years; and with first, 
in 1758, the suspension, and then, in 1776, the repeal of the Cattle Acts. This was a phase of firm British demand for Irish farm produce, especially grain, butter and pig meat. It gave rise in southern Ireland-uniquely outside tropical riverine and monsoon crop-growing areas-to an agricultural proletariat that became the largest social class in the land. The genesis of the Irish agricultural proletariat lay in a combination of peculiar production conditions that required grain crops to be frequently interspersed with potato crops, a highly competitive land market, and relatively low cattle prices. This combination of circumstances made it transiently possible for capital-less young persons in Ireland to produce from land a subsistence and a surplus for competitive rent. The capital-less Irish, uniquely in a less hospitable northern climate, did it by growing, on land exhausted by grain crops, enough potatoes for subsistence and for fattening pigs that were sold to pay a higher rent than graziers of relatively low-priced cattle could afford. The birth rate was forced towards its biological limit, as in all 'traditional' societies where a subsistence can be got without capital. Land profits were enhanced in the process by the proceeds of pig sales. There is an almost perfect correlation $\left(r^{2}=0.98\right)$ between the growth of population and of pig exports in Ireland between 1712 and 1831; an additional pig was exported for every increase of seven in the pcipulation' (Connell, 1950:25; Crotty, 1966 : 2.77).

The combination of circumstances that was the necessary and sufficient condition for the growth of an agricultural proletariat that was restricted only within biological limits did not obtain in all parts of Ireland. The rights in land which the protestant tenants of northern Ireland had, as members of the armed, planter, garrison class, made the land market there less competitive. Capital-less young people had less ready access to land. They were compelled instead, like their coevals in England, to work at the expanding textile industry; linen in Ireland and wool in England.

\section{Union}

Apprehension that the highly developed Irish colony, which by the end of the eighteenth century had a considerable degree of autonomy, would follow the American path to republicanism and, in so doing, provide a dangerous foothold for imperial Britain's competitors and enemies was a factor in bringing about the political and economic union of the two islands in 1800 . Equally important was the fact that Britain's economy had developed beyond the stage where it had anything to fear from Ireland's competing imports to the stage where its mushrooming factories had much to gain from freer access to the considerable Irish market. The Act of Union, passed by the Westminster and Dublin Parliaments, had no less support from Irish public opinion. This, as conceived and expressed at the time, was as favourable to Union in 1800 as it was to Ireland's recent accession to the EEC which was supported in a referendum by fourfifths of the electorate (Bolton, 1966).

The century following Union, the high noon of empire for Britain, was a time of unmitigated disaster for Ireland. In probably the first, and certainly the most extreme, case of the now much better understood and documented phenomenon of core economies developing at the expense of peripheral ones, Britain grew to dwarf and shade the neighbouring economy.

It was, in Britain, the age of modern factory capitalism. The single most critical consequence for Ireland of the growth of British factory capitalism has been the increase in demand for beef relative to other farm products. This, since Waterloo, has caused the price of beef in Ireland to quadruple relative to the price of wheat and to double relative to the price of butter. It has made profitable the substitution of labour extensive cattle rearing for all other activities. It has caused the human population of southern Ireland to decline from seven to three million and the cattle population to increase from two to six million between 1841 and 1971 (BPP 1843; Ireland, 1974).

Movement of labour from agriculture into manufacturing industry, to replace imports or to produce for export, was a theoretically possible adjustment in the open Irish economy. Pressure of population and unemployment should have reduced wages, making Irish industry more competitive at home and abroad, as proponents of an incomes policy in Ireland now argue. There were two offsetting considerations. First, as land was transferred from crop-growing to cattlerearing, the supply of agricultural raw materials for processing either ceased to expand or declined: production of milk for the dairy industry did not increase from 1830 to 1960; grain production for the milling industry declined; output of pigs stabilised and many were diverted from the bacon industry to the live trade; and though cattle output increased, the live trade took an increasing proportion and soon all of the output, ending a centuries-old provision trade. Second, income decline in the age of factory capitalism and on the isolated periphery, is a 
double-edged affair. Lower wages imply a contracting home market and, therefore, higher fixed costs per unit, which are unlikely to be sufficiently offset by wage reductions to make exports possible. Lower wages can in this way result in competing imports absorbing a larger proportion of a declining market.

Famine, disease and emigration removed the agricultural proletariat that, with rising cattle and sheep prices, no longer yielded a profit to land, and could not be transformed into an industrial proletariat. Labour and savings were drained abroad, where, being rootless, mobile and adaptable, they frequently operated in the van of the capitalist core's expansion, deployed a! missionaries, soldiers, teachers, administrators, planters, labourers, ${ }^{1}$ or as risk capital, wherever they yielded the highest profit and best expedited the 'growth of empire'. It was a pattern, once established, of stable decline: the outflow of resources kept the peripheral economy small and inefficient, ensuring low returns that would continue to drive resources abroad; and the outflow created a political vacuum that precluded the radical, structural changes necessary to raise productivity.

Cultural absorption was part of the integrating process. The Gaelic language that survived the violence of the sixteenth and seventeenth centuries and the attempts, in the eighteenth century under the Penal Laws, to root out the indigenous culture, continued to be the language of the majority up to the Union. Its subsequent decline was rapid. A typical contemporary observation in the early nineteenth century was that Gaelic "is falling a good deal into disuse among them; the tradespeople transacting their business in English for the most part, so that the poor Irishman now finds it to his advantage to know that language for more easy communication in his dealings" (Shaw Mason, 1819). Cultural absorption facilitated economic integration; it facilitated the inflow of manufactured goods and the outflow of labour and savings.

The Irish periphery's population declined from 6.8 to 4.5 million while the English core's increased from 11.3 to 33.6 million between 1821 and 1911. (British Parliamentary Papers, 1822, 1824, 1912-13 and 1914-16.) Decline in the periphery was not uniform however. The population of the predominantly protestant northern Ireland was the same in 1911 as in 1821: 1.4

1 Engels referred less flatteringly to the flood of Irish emigrants as fulfilling "the notorious function of supplying England, America, Australia, etc.; with prostitutes, casual-labourers, pimps, thieves, beggars and other rabble" (Marx and Engels, 1943). million. The entire 2.3 million population decline occurred in the overwhelmingly catholic south. These very different demographic experiences owed little to divergences in dogma, but much to divergences in status: of privileged and oppressed, of garrison and garrisoned, which in Ireland was distinguished by religion as in other colonies it was to be distinguished by race.

Northern Ireland maintained its population because of the growth of Belfast. That, in turn, was based on linen and shipbuilding. Protestant privilege, as expressed by the 'Ulster custom' of tenant-right, had caused the concentration of flax-growing and the linen industry in the north before the Union. The impetus of this early industrialisation in the north was maintained after the Union by three factors, despite the centripetal pull that denuded the rest of the Irish periphery of industry. First, linen, alone of the staple Irish export industries, continued to have its raw material locally produced in increasing quantities; flax-growing was the only agricultural enterprise that could compete in nineteenth century Ireland with the rearing of store cattle for the-British market. Second, northern Ireland's secondary manufacturing industry, shipbuilding, which evolved from the linen industry, was peculiarly well suited to minimise the disadvantages of distance from raw materials (by adding greatly to their value before re-exporting them) and from markets (by floating the product to these), and to get maximum benefit from the area's third strength-its disciplined, adaptable labour force.

The garrison status of northern Ireland protestants, a reaction to their massacre by the island's catholic majority in 1641, 1688 and 1798, created an identity of interest between protestant labour and protestant capital that was conducive to tight industrial discipline and innovation. Discipline and innovation were the more readily acceptable by protestant workers because much of the cost could be placed on the catholic helot class, to whom were relegated the lower paid, less congenial and less secure employments.

\section{Economic integration: political disintegration}

The core's growth and the periphery's decline transformed the relative class structures of the two regions. Almost every other person surviving to adulthood left Ireland, to make way for cattle and to swell the proletariat in England and other growth centres, leaving in southern Ireland a residual population of which the bourgeoisie became an ever-increasing proportion. As the class structures of the two regions of the United Kingdom of Great Britain and Ireland changed, 
so their class interests diverged. The British connection, deemed essential at the beginning of the nineteenth century to thwart a Jacobin takeover in Ireland, was, by the end of the century, seen, increasingly, as a threat to Irish bourgeois interests, made otherwise absolutely secure in the southern part of the island by the regular outfiow of that half of the oncoming population who had neither jobs nor property, but who found it easier to change their domicile than the social order in their birthplace. The southern catholic, pastoralist, Irish bourgeoisie, more secure within Ireland than the ruling class in any other European country, were prepared to secede from the Union to advance or to defend their vital class interests. They threatened to do so in 1880 in order to end the payment of rents to the heirs of the original confiscators of Ireland's tribal lands, and were bought off by successive Land Acts which, with financing from the British core, transferred title from landlords to grazieroccupiers. The southern Irish bourgeoisie did secede from the Union when Britain in 1917 attempted to conscript their sons (hunger having years earlier driven the remnants of the Irish proletariat into Britain's army).

The bourgeoisie on both occasions appropriated and adapted for their own purpose existing populist, radical movements. The agrarian movement of the Mayo smallholders and cottiers that, under pressure from expanding cattle stocks, sought to nationalise land became the Irish Land Conference of representatives of Irish cattle graziers and of Irish and Anglo-Irish landlords. This, under the chairmanship of the Earl of Dunraven, agreed that ownership of the land should be transferred from landlords to farmers, the British State being called upon "to bridge the gap between the price the owners could afford to take and the price the tenants could afford to give" (Crotty, 1966). The aborted socialist republic of 1916 became the Irish Free State of the 1920s that, before 'demand management' made government borrowing respectable, cut old age pensions to balance a flagging budget.

A Britain moving towards a social democracy that was anathema to the southern Irish bourgeoisie had as little stomach for coercing Ireland to remain within the Union as it had for maintaining an empire. Only the north, where the protestant garrison was concentrated, where emigration was lower and where, therefore, class structures and class interests diverged less from those of the British core, opted to remain within the Union.

Bourgeois interests were conserved after southern Ireland's secession by continued, accelerating emigration. Taxes on property or on the incomes from it are nominal (landowners effectively pay no income-tax) in an economy where tax rates are otherwise more than usually high. Possession of property is secure to the point where no farmer has been evicted from his land, by due process, since the establishment of the State. Land values, partly as a result, have further appreciated from $£ 20$ per acre in 1815 to $£ 1,500$ per acre now. The value of land is far higher in Ireland, relative to GNP, than in any other country, and almost half of this land is owned by 1 per cent of the population (Ireland, 1974).

Attempts have been made, within the limits of vested bourgeois interests, to restructure the southern Irish economy. Protection was attempted in the 1930s, but the high prices and poor quality of protected manufactured goods fed emigration. More recently, exporting industry has been encouraged by capital grants and tax-holidays, ${ }^{2}$ financed through government borrowing, but the jobs created have been fewer than the jobs lost. However, the conservatism that brought the Irish State into existence, that has been displayed throughout 55 years of self-government, and that is measured by soaring land values and declining job numbers, offers no prospect of the radical action necessary to deal with the fundamental change in the circumstances of the Irish periphery caused by Britain's retreat from empire.

\section{The end of a relation}

The two crucial elements in a gathering Irish crisis are jobs and religion. Ireland, for almost 150 years on the periphery of the British core of empire, has provided jobs for half its people; the other half perished or emigrated. Much has changed in the Irish periphery, but not the loss of jobs. This, in southern Ireland, was 0.6 per cent annually throughout the nineteenth century and has continued at 0.3 per cent in the twentieth. Adjustment to continued, long term job losses was avoidable while the British core remained the heart of empire and could redeploy the Irish periphery's surplus resources. But with the passing of empire, that facility no longer exists; Irish emigration has ended, more swiftly than it

\footnotetext{
2 Tax-h-lidays in Ireland make it possible for MNCs locating part of an integrated process there to get tax-holidays elsewhere also. Shipping 2 million tons of bauxite and 300,000 tons of crude-oil annually from West Africa for processing into 200,000 tons of alumina at a proposed plant at Shannon, southern Ireland, only makes sense if the bauxite is charged in at a price that registers a loss and therefore no tax liability in Guinea, and the alumina is charged out at a price that registers similar losses and zero tax liability on smeltering and fabricating operations in Britain and other Eurcpean countries. All of the profits of the integrated process can be credited to the Irish plant, where they are tax-free.
} 
commenced 140 years ago. The south's population, reduced by 5 per cent by emigration in the 1950s, is now increasing for the first ime in 130 years, at a rate similar to that which culminated in the Great Famine of the 1840s.

The northern situation is scarcely less grave. Linen and shipbuilding are obsolescent and cannot easily be replaced by industries that so felicitously minimise the weaknesses and maximise the strengths of the situation. Moreover, what was a strength in expansion has become a weakness in decline. The privileges of the protestant garrison acquire a new significance in an island where jobs are only available for half the population and where, because of the run-down of empire, the other half can no longer leave for redeployment in the British core. Privilege is the more obdurately defended by the protestant holders and the more bitterly resented by the catholics over whom it is exercised, as its value increases. Tensions are not eased either by the raising of levels of educational attainment which, as in many other parts of the former empire, have so far been more successful in creating an awareness of deprivation than in identifying means of rectifying it. The religious tensions, that formerly were a source of industrial strength, have deteriorated into sectarian strife, to add to the handicaps of a peripheral location and a small market.

The gravity of the situation has been contained in the south by massive internal debt creation which, in 35 years, has given the Irish State a national debt that costs more to service, relative to GNP, than that of any other country (Central Bank of Ireland, 1977). More recently, through high inflation the debt has spilled over into external borrowing that also places Ireland foremost with respect to sustained balance of payment deficits relative to GNP, and on a scale beyond the capacity or willingness of the London money market to supply. ${ }^{3}$ External borrowing is now principally in Eurodollars, the cost of servicing which in Irish currency - the punt-increases with every slide in the exchange value of the currency (Central Bank of Ireland, 1977).

The island also benefits from an annual net transfer by the British Government to northern Ireland of resources worth some $\$ 500 \mathrm{mn}$, and by the purchase, at an annual cost of $£ 150 \mathrm{mn}$, by the EEC of southern Ireland's dairy produce,

3 The principal difference between the Government that came into office in the Irish Republic in June, 1977, with the largest majority in the State's history, and the one it replaced is a commitment to reduce taxes, to increase public sector sponding, and to bridge the finance gap by still greater external borrowing. to add to the EEC's butter and milk-powder "mountain". These transfers have so far made possible welfare payments to the unemployed in northern and southern Ireland, but they have not changed the 130-year-old downward slide in job numbers, nor the startling growth of unemployment as population grows more rapidly in Ireland now than in any other European country.

The old, populist, deeply-rooted tradition of violent, blind, ineffective protest, first against the confiscation of land, and then against that set of social conditions which, for a century-and-a-half has forced every second person to emigrate, acquires a new significance in these circumstances. The degree of coercion practised by British forces in the past in Ireland to suppress violence is increasingly unacceptable to a British social democracy that has shed its imperial interests and is kept vividly informed by the media. Simultaneously, the head of violence will no longer be relieved by emigration; that half of the population stream for which there is no place within the Irish economy as now organised must back up into a great lake of unemployment, threatening to sweep away the institutions of government imposed in the first instance by imperial Britain, and secured thereafter by a British army or by the outflow of those whom the institutions disinherited. Britain's retreat from empire has made fundamental change in Ireland inevitable, and virtually certain within the coming decade. The course of change in Ireland now is no less relevant to Britain, as it adapts to its own new role on the periphery of the European economy, than it was when Ireland secured imperial Britain's western flank. There is little present prospect that change in Ireland will be radical and orderly. The indications instead are that it will be revolutionary and chaotic.

\section{References}

Bolton, G. C., 1966, Passing of the Irish Act of Union, OUP, Oxford

Bottigheimer, Karl, 1972, English Money and Irish Land: the adventurers in the Cromwellian settlement of Irish Land, OUP, Oxford

British Parliamentary Papers 1822 (502) XV. Abstracts of Answers and Returns of the Population of Great Britain in 1821

British Parliamentary Papers 1824 (577) XXII. Abstracts of Answers and Returns from Taking an Account of the Population of Ireland in $182 I$

British Parliamentary Papers 1843 (Cd 504) Vol. XXIV. Report of the Commissioners Appointed to Take the Census of Ireland for the year 1841 
British Parliamentary Papers 1912-14 (Cd 6663) CXVIII. Census Returns of Ireland 1911. General Report

British Parliamentary Papers 1914-16 (Cd 7929) LXXXI. Census Returns of England and Wales 1911. Summary tables

Central Bank of Ireland, 1977, Annual Report

Clarke, A., 1976, 'The Irish Economy, 1600-1660', in T. W. Moody, F. X. Martin and F. J. Byane (eds.) A New History of Ireland, Vol 3, OUP, Oxford

Connell, K. H., 1950, The Population of Ireland, 1750-1845, OUP, Oxford

Crotty, R. D., 1966, Irish Agricultural Production: Its Volume and Structure, Cork University Press, Cork
Cullen, L. M., 1968, Anglo-Irish Trade 1660-1800, University Press, Manchester

Ireland, 1973, Census of Population 1971, Vol. 11, (Prl 3462)

Ireland, 1974, Statistical Abstract of Ireland 1970-71, (Prl 1974)

Maguire, W. A., 1972, The Downshire Estate in Ireland 1801-45, OUP, Oxford

Marx, K. and Engels, F., 1936, The Selected Correspondence of 1846-95, Lawrence and Wishart, London

Mason, Wm. Shaw, 1819, A Statistical Account or Parochial Survey of Ireland drawn up from the communications of the clergy Vol. 3, Faulkner Press, Dublin

Wallerstein, I., 1974, The Modern World System, Academic Press, New York and London 